\title{
RELEVANCE OF RIGHT TO ECONOMIC SELF-DETERMINATION (RESD) PRINCIPLES OF INDONESIAN SOVEREIGNTY IN BILATERAL INVESTMENT TREATY (BIT)
}

\author{
Dr. Mutia Evi Kristhy, S.H., M.Hum \\ Fakultas Hukum Universitas Palangka Raya \\ Email : mutiaevi@yahoo.com \\ Dr. H. Suriansyah Murhaini, S.H., M.H \\ Fakultas Hukum Universitas Palangka Raya \\ Email :wr2upr2018@gmail.com
}

\begin{abstract}
The RESD principle is relevant for protecting the sovereignty of the Indonesian state in BIT negotiations, formulations and implementation. This relevance is based on the willingness and ability of the Indonesian state to exercise its sovereign authority responsibly in managing foreign investment. Accountability of sovereignty functions in the context of foreign investment can be proven through the willingness and ability of the functions it carries to ensure the availability of political good and public good to all parties who invest in their jurisdiction. Proving the country can be done through three main principles of the implementation of state sovereignty, namely responsibly, in accordance with good governance, and international standards of civilization. These three principles are manifested in the country's willingness and ability to guarantee political good in carrying out foreign investment relations with foreign investors and partner countries. Political good in this context is democratic governance (rule of law), good governance (anti-corruption). The implication of this legitimacy is that the state is spared or even cannot be interfered by other authorities, because it has a bargaining position.
\end{abstract}

Keywords: Right to Economic Self-Determination (RESD), Bilateral Investment Treaty (BIT), Sovereignty.

\section{Introduction}

One manifestation of the nature of a sovereign nation to determine its own destiny is the right to determine its own economic destiny or Right to Economic Self-Determination (RESD). RESD is the right of every country to act autonomously in managing internal economic affairs and its nature is independent from outside intervention on the implementation of the economic policy or regulation.
The 1945 Constitution mandates RESD to realize economic sovereignty as mandated in Article 33 of the 1945 Constitution. In associating with the concept of the welfare state and state function, RESD as the state's right to control stated in Article 33 of the 1945 Constitution positions the state as a regulator and guarantor of people's welfare, determine how to realize the general welfare (Asshiddiqie, 2006) and become a guide in every 
step of economic policy taken by the Indonesian state (https:/ / mkri.id).

In order to realize the welfare of the people, Indonesia as a sovereign nation realizes the importance of building an economic cooperation as an effort to achieve the goals of the welfare state as stated in the opening of the 1945 Constitution and the goals of national development. Economic cooperation for the development of economic sectors in Indonesia, such as; agriculture sector, forestry sector, fisheries sector, mining sector, industry sector, trade sector, service sector and others, which can be done through Foreign Investment (hereinafter referred to as PMA). Foreign investment activities to transform economic potential into real economic strength using capital, both from domestic and foreign sources (Strategic Plan for the Investment Coordinating Board (BKPM) 2015-2019).

Indonesia's

economic

cooperation relations with partner countries have begun since Indonesia proclaimed its independence on August 17, 1945. Various economic forums, both bilateral, regional and multilateral, have been designed by Indonesia together with friendly countries. In establishing this relationship, Indonesia continues to promote forms of community life that uphold the values of mutual respect, not interfering with affairs in other countries, by prioritizing consensus and consultation in the decisionmaking process (https://www.kemlu.go.id). The Government of Indonesia since January 10, 1967 has issued a policy on investment, and then promulgation of Law Number 1 of 1967 concerning Foreign Investment, as amended by Law Number 11 of 1970, then by enactment of Law Number 6 Year 1968 concerning Domestic Investment.

The regulation of investment activities in Indonesia is regulated in Law No. 25 of 2007 concerning Investment (Supancana, 2006). PMA is considered to be able to make a real contribution (http:/ / www.bphn.go.id/), to move the wheels of economic development within the framework of fostering good relations between countries, as well as awareness to achieve common goals and interests (mutual interest) through cooperation in the fields of promotion and increase investment, one of which is through the Bilateral Investment Treaty (BIT).

BIT functions as an international legal instrument to support PMA governance that is built on the premise of reciprocal relations or mutual benefits between investment protection for investors in exporting countries (home state) on one side and economic growth and prosperity of the country host (host state) on the other hand (Sauvant, 2008).

PMA is seen as a very profitable field for the host, while BIT is assumed as a legal instrument for the promotion of FDI inflows by giving investors investment protection and showing the host country's openness to foreign investment (Kaushal, 2009). BITs made and agreed by Indonesia with partner countries can provide protection for both parties.

As previously stated, the existence of a BIT is basically to 
guarantee the rights and obligations between the two countries that agreed on the agreement. The BIT agreement is made and agreed upon by the Indonesian government with partner countries, within which there are also provisions regarding definitions of the terminology used in the agreement, what things can be done and cannot be done by both countries, scope, the basic principles required in a BIT (Nasution, 2007).

The signing of the BIT has been seen as a means for developing countries to build relationships with countries that can provide increased trade and funding, intensify economic relations between the parties involved, protect investment, increase technology transfer and capital inflows, and facilitate economic development host country (Salacuse, 2010).

Developing countries consider PMA important for modernization and development, so their participation in the BIT regime is a vital provision needed (Salacuse, 2010). BIT becomes a vital provision in the global investment regime, so developing countries and developed countries sign BIT, so that this agreement provides substantive and procedural rights to foreign investors, the next consequence is that investors will invest in the host country. In signing the BIT there is a very visible gap between developed and developing countries in two different perspectives, developed countries try to establish BIT to protect investors and their investments from unilateral actions of the host country, while developing countries sign BIT with the aim that this signing will impact on increasing inflows of Foreign Direct Investment (FDI) for national economic development (http:/ / unctad.org).

For developing countries, signing a BIT is very reasonable, because in the past few decades PMA has been believed to be the main driver of economic growth in many countries in the world (Schreuer C, 2008). Theoretically, the signing of the BIT consequently increases PMA, thereby encouraging the economic development of developing countries. PMA can encourage the entry of foreign capital; new job creation; transfer of new management practices and new technologies; increased domestic production; more advanced domestic market; stronger institutional capacity; and reducing dependence on foreign aid and foreign debt to encourage poverty reduction and other development initiatives (Boone, 2011). BIT is designed to create clear rules and mechanisms for regulating foreign investment. The basic provisions of the BIT usually guarantee the standard of preferential treatment to foreign investors (UNCTAD, 1999). Signing the BIT means that the country has agreed to provide certain relative standard treatment as determined by the articles contained in the BIT.

\section{Discussion}

Indonesia as a sovereign country in the economic field, as mandated in article 33 of the 1945 Constitution, has the right to determine the policy of managing all wealth and excellence as stated above for the welfare of the people. 
Indonesia has independent or free rights to determine policies to manage natural resource wealth, and the large population for national economic development purposes and has the authority to set the direction and policy of investment agreements in relations with other countries and investors who wish to invest in Indonesia to take advantage of the advantages possessed by Indonesia.

But on the other hand, when entering into the context of PMA and BIT cooperation, the Indonesian RESD's claim on all of this was collided with internal factors or political good that eroded the claim. As reported by the World Bank about the results of its survey of 155 countries shows that the investment climate in Indonesia is classified as middle class. The intended investment climate includes economic and political stability, certainty and rule of law, governance that is far from ideal and corrupt practices (Mantiri, 2011).

Based on the description above, that the claim on RESD to protect economic sovereignty has full authority, so that it can determine investment policies that are negotiated with partner countries in the form of BIT highly dependent on Indonesia's ability to realize a good investment climate (political good) in the investment sector. Therefore, in order to have full authority in determining investment policies negotiated through the BIT, the Indonesian government must be willing and able to show performance on four key indicators of political good, namely: democracy, good governance, rule of law, and eradication of corruption.

BIT is a legal instrument to protect investors from risks faced in investment destination countries. For investors, investment destination countries or capital importers which in fact are developing countries are high risk countries. Therefore, the signing of the BIT serves to address investors' concerns about the risk, one of which is the risk of the stability of the host country's investment environment. The facts show that there are different behaviors between developed and developing countries in signing BIT. BIT agreements among developed countries are only a small fraction of the total BIT ratified. This makes sense because the need for BIT is much smaller for developed countries because the risk of investment in developed countries is relatively small. In contrast, the BIT agreement between developed and developing countries dominates the overall BIT agreed upon. This is motivated by the country risk factor, developing countries are considered too risky to be the host country for FDI.

For developing countries, the ratification of BIT is a risk guarantee for FDI so that investors feel safe because their investments are protected (Berger, et al., 2013). The issue of country risk is a fairly dominant factor and becomes the basis for consideration in carrying out investment activities. The aspect of country risk that is highly considered by investors is economic and political stability. The main condition for a country to attract investors is political and economic 
stability. Investors pay close attention to political and economic stability if they want to invest their capital in a country, therefore, when agreeing on an investment agreement with another country, each host country assures investors of stability guarantees.

Democracy is the best instrument to promote political stability, sustainable development and sustainable economic growth (Bowden, 2004). There are several reasons that support this argument:

First, a true democratic process can produce a democratic and legitimate government. Government legitimacy is very important because it will guarantee the continuity of the government and its policies. Conversely, the lack of legitimacy of the regime will have an impact on stability, regime changes and policy changes can occur at any time. In the perspective of investor interests, instability and policy changes are a serious threat.

Second, when the level of democracy increases, protection and certainty increase, compared to less democratic governments, democratic governments allow economic stability, long-term economic growth rates, and the ability to adapt quickly if global changes occur. Democracy creates a more stable policy environment and lower political risk.

Third, democracy is a system that has a great opportunity to guarantee the implementation of a check and balance mechanism for all state policy products, including policies in the economic field. This mechanism guarantees the involvement of all stakeholders to evaluate economic policies, whether the policies are in accordance with the objectives of the public interest and are based on applicable legal rules.

Democracy manifested in the General Election prevents the elected government from changing policies that are not in accordance with the promise, because the government must be accountable to the people who have chosen them. Conversely, governments that are undemocratic or not elected through free and transparent elections are very risky for their own people and foreign investment.

The negative perception of a country's democratic process has a negative impact on the perception of foreign investment, consequently having an impact on bargaining power in BIT negotiations due to high risk. In this sense, democracy acts as an instrument to guarantee a stable policy environment, because democracy functions as a mechanism to avoid the arbitrariness of policy changes that can harm investors (Jakobsen, J, 2006).

As is well known, that political risk in terms of policy stability is considered a major determinant of foreign investment, while checks and balances in the democratic system are believed to be able to prevent the government from irresponsible policy changes, thus democracy is positively correlated to investment so that the consequences on the bargaining power of the government in BIT negotiations and formulations.

In the perspective of investors, countries where democracy is generally respected are considered 
more attractive to host FDI compared to undemocratic (Ursprung, 2001). This perspective is motivated by the reason that the implementation of democratic governance is considered as the most stable form of government and policy stability is considered as the main determinant of FDI (Busse, 2003).

The researcher believes that the level of democracy of the host country affects the bargaining power of the host country in the BIT negotiations. This correlation departs from the function of the BIT as an instrument of guaranteeing security and protecting foreign investment, where the protection of foreign investment is highly dependent on the political and policy risks of the host country. Democracy reduces the risk of political instability, and when political risk in the country decreases, the bargaining power to convince investors and capital-exporting countries is high in line with their perceptions of democratic performance as reflected in the host country's democratic index (Busse, 2003).

The Economist Intelligence Unit (EIU), one of the Economist's research institutes, has released the 2017 World Democracy Index on January 30, 2018. World democracy presents an assessment of the sustainability of democracy in every country in the world, measured using five assessment variables. The five democratic index assessment variables include; (1) electoral processes and pluralism, (2) functioning of government, (3) political participation, (4) political culture, and (5) civil liberties.

The assessment results measured from the five variables produce an average score which is used as a benchmark for ranking indexes. Three Northern European countries, including Norway, Iceland and Sweden, respectively ranked the top three in the index. Norway recorded a score of 9.87 followed by Iceland with a score of 9.58, and Sweden with a score of 9.39. Each country has a perfect or near perfect rating on five index rating variables. New Zealand has the highest ranking of all countries in the Asia Pacific region.

Indonesia is in the 68th position. As reported by The Economist, Indonesia has an average score of 6.39. The Economist noted, the electoral process variable and Indonesian pluralism had a score of 6.92. Meanwhile, the functioning variable of the Indonesian government has a score of 7.14, the highest score out of a total of five assessment variables. Meanwhile, the variables of political participation, political culture, and civil liberties of Indonesia have a score of $6.67 ; 5,63$; and 5.59. The Economist said that Indonesia's position in the index dropped sharply in the 20th rank from the 2016 calculation (Index Democracy, 2017).

In line with the EIU report, the National Statistics Agency (BPS) also reported a decline in the Indonesian Democracy Index (https://www.bps.go.id). According to BPS, the 2016 Indonesian Democracy Index reached 70.09 on a scale of 0 to 100 . 
This figure has decreased compared to the 2015 IDI figure. The phenomenon of a decline in Indonesia's democratic index in the last two years reported by international and national institutions is an important note for investors and the Indonesian government itself.

For investors, the decline in the democratic index builds the perception that investment in Indonesia is risky because the potential for political instability increases. As for the Indonesian government, when political risk increases, the bargaining power to convince investors and capitalexporting countries is low in line with their perceptions of the democratic index in Indonesia. Based on the premise that there is a positive correlation between democracy and BIT, it can be concluded that democratic indicators are an important aspect so that Indonesia can claim RESD. The better democracy in Indonesia, the higher bargaining power in BIT negotiations. The logical consequence is that for the RESD claim in the BIT negotiations, Indonesia is required to improve democratic performance so as to increase its bargaining position. Therefore the claim on RESD is very dependent on the performance of the government to guarantee a good democratic process in order to guarantee domestic political and economic stability.

\section{Conclusion}

The RESD principle is relevant for protecting the sovereignty of the Indonesian state in BIT negotiations, formulations and implementation. This relevance is based on the willingness and ability of the Indonesian state to exercise its sovereign authority responsibly in managing foreign investment. Accountability of sovereign functions in the context of foreign investment can be proven through the willingness and ability of the functions it carries to ensure the availability of political good and public good to all parties who invest in their jurisdiction. Proof of the state can be done through three main principles of the implementation of state sovereignty, namely responsibly, in accordance with good governance, and international standards of civilization. These three principles are manifested in the country's willingness and ability to guarantee political good in carrying out foreign investment relations with foreign investors and partner countries. Political good in this context is democratic governance (rule of law), good governance and anti-corruption. The implication of this legitimacy is that the state is spared or even cannot be interfered by other authorities, because it has a bargaining position and has equal etiquette. Indonesia is not easy to dictate or interfere when negotiating and implementing BIT with investors and partner countries. The construction of the RESD principle is based on guaranteeing four aspects of political good, RESD is relevant for protecting sovereignty in negotiating and implementing the Indonesian BIT model for three main reasons; First: executive, judicial and legislative measures or policies of the Indonesian state win the trust of 
investors and partner countries; Secondly, the Indonesian state has judicial equality in resolving every investment dispute and civil society equality as an international community so that the country has a high bargaining position in global economic political negotiations; and Third, the ability of countries to realize political good in PMA measures and policies to be the main capital or competence to compete at the global level.

\section{References}

A. F. Elly Erawati dan J. S. Badudu, 1996, Kamus Hukum Ekonomi Indonesia Inggris, Edisi Pendahuluan, ELIPS, Jakarta. Andreas Halim, 2003, Kamus Lengkap 1 Milyar Inggris-Indonesia, Sulita Jaya, Surabaya.

Asha Kaushal, 2009, “Revisiting History: How the Past Matters for the Present Backlash Against the Foreign Investment Regime", Harvard International Law Journal, NY, Volume. 50. No. 2.

Axel Berger, et al., 2013, "Do Trade and Investment Agreements Lead to More FDI? Accounting for Key Provisions Inside the Black Box", International Economics and Economic Policy, Volume 10, No. 2, lihat di

http:/ / www.lusem.lu.se/libr ary.

Bismar Nasution, 2007, Hukum Kegiatan Ekonomi, Books Terrace\&Library, Bandung.

Brett Bowden, 2004, "In The Name of Progress and Peace: The Standard of Civilization and
The Universalazing Project", Alternatives, Volume. 29, No. 1.

Departemen Pendidikan dan Kebudayaan RI, 1995, Kamus Besar Bahasa Indonesia (KBBI), Edisi ke empat, Balai Pustaka, Jakarta.

Dolzer Rudolf, Schreuer C, 2008, Principles of International Investment Law, Oxford University Press.

I.B.R. Supancana, Editor Tana Mantiri, 2011, Kompedium Hukum Investasi, Badan Pembinaan Hukum Nasional Kementerian Hukum dan HAM RI, Jakarta.

Ida Bagus Rahmadi Supancana, 2006, Kerangka Hukum dan Kebijakan Investasi Langsung di Indonesia, Ghalia Indonesia, Bogor.

Indeks Demokrasi Indonesia di Tingkat Nasional Menurun, Tahun 2015, lihat di https:/ / www.bps.go.id/pres srelease/2017/09/14/1401/i ndeks-demokrasi-indonesia-idi--tingkat-nasional-2016mengalami-penurunandibandingkan-dengan-iditingkat-nasional-2015.html.

Index Democracy, 2017, Economist Intelligence Unit, The Economist Intelligence Unit's Index of Democracy, lihat di http:/ / pages.eiu.com/rs/753 -RIQ438/images/Democracy_Ind ex_2017.pdf.

Jakobsen, J, 2006, “Does Democracy Moderate the Obsolescing Bargain Mechanism? - An Empirical Analysis 19832001". Transnational 
Corporations, Volume. 15, No 3. hlm. 67-106, lihat di http://unctad.org/en/docs/ iteiit20063a3_en.pdf.

Jeswald W. Salacuse, 2010, "The Emerging Global Regime for Investment", Harvard International Law Journal, NY, Volume. 51, No. 2.

Jimly Asshiddiqie, 2002, Konsilidasi Naskah UUD 1945 Setelah Perubahan Keempat, FH UI, Jakarta.

Jimly Asshiddiqie, 2006, Teori Hans Kelsen Tentang Hukum, Setjen dan Kepaniteraan MK-RI.

Joshua Boone, 2011, "How Developing Countries Can Adapt Current Bilateral Investment Treaties to Provide Benefits to Their Domestic Economies", The Global Business Law Review, Cleveland State University. Karl P. Sauvant, 2008, Appeals Mechanism, International Investment Dispute, Oxford University Press, New York.

Kementerian Luar Negeri Republik Indonesia, lihat di https: //www.kemlu.go.id /id / kebijakan /Pages / kerjasama- bilateral.aspx.

Lembar Negara 1970 Nomor 46, TLN 2943.

Lembar Negara. 1967 Nomor 1, TLN 2818.

Lembar Negara1968 Nomor 33, TLN 2853

Mahkamah Konstitusi Republik Indonesia, 2008, Risalah Sidang Perkara Nomor 21/PUU-V/2007, Perkara Nomor 22/PUU-V/2007,. Lihat dalam https://mkri.id/public/cont ent/persidangan/risalah/ris alah_sidang_Perkara \%202122.puu2007,\%2025\%20maret $\% 20200$ 8\%20_Putusan_.pdf.

Mattias Busse, 2003, "Democracy and FDI", Hamburg Institute of International Economics (HWWA) Disscusion Paper, Hamburg, Germany.

Philipp Harms and Heinrich W. Ursprung, 2001,"Do civil and political repression really boost foreign direct investments?", Independent Institute Working Paper, No. 36. Pramoto Waluyo, "Aspek Hukum Dalam Peningkatan Penanaman Modal Asing (PMA) Melalui Pengembangan Kawasan Perdagangan Bebas dan Pelabuhan Bebas", Paper, Biro Hukum dan Humas BKPM, hlm. 1-8, lihat di http://www.bphn.go.id/dat a//paper_pratomo_bkpm.do c.

Rencana Strategis Badan Koordinasi Penanaman Modal (BKPM) 2015-2019.

UNCTAD, 1999, Trends in International Investment Agreements: An Overview, United Nation.

Undang-Undang Nomor 12 Tahun 1970, Lembar Negara 1970 Nomor 47, TLN 2944 